\title{
PENGARUH DAYA LEDAK TUNGKAI, KOORDINASI MATA KAKI DAN PERCAYA DIRI TERHADAP KEMAMPUAN SHOOTING KE GAWANG DALAM PERMAINAN SEPAKBOLA PADA SISWA SMAN 2 KOLAKA
}

\author{
JUMAKING \\ Universitas Sembilanbelas November Kolaka, e-mail: jhoemaking.usn@gmail.com
}

\begin{abstract}
Abstrak
Penelitian Ini adalah jenis pe nelitian Ex Post Facto yang menggunakan rancangan penelitian analisis jalur. Populasi adalah seluruh siswa SMAN 2 Kolaka yang mengikuti kegiatan ekstrakurikuler dengan jumlah sampel yaitu 30 siswa. Teknik penentuan sampel adalah total populasi atau sampel jenuh. Teknik analisis data yang digunakan adalah analisis deskriptif, uji persyaratan, analisis jalur melalui program Spss 20.00 pada taraf siginifikan $95 \%$ atau $\alpha 0,05$. Hasil penelitian menunjukkan bahwa ; (1) Ada pengaruh langsung daya ledak tungkai terhadap percaya diri pada siswa SMAN 2 Kolaka dengan nilai beta yaitu 0,500 dengan tingkat signifikan $0,000<\alpha 0,05$; (2) Ada pengaruh langsung koordinasi mata kaki terhadap percaya diri pada siswa SMAN 2 Kolaka dengan nilai beta yaitu 0,505 dengan tingkat signifikan 0,000 $<\alpha 0,05$; (3) Ada pengaruh langsung daya ledak tungkai terhadap kemampuan shooting ke gawang dalam permainan sepakbola pada siswa SMAN 2 Kolaka dengan nilai beta yaitu 0,419 dengan tingkat signifikan 0,001 < $\alpha 0,05$ (4) Ada pengaruh langsung koordinasi mata kaki terhadap kemampuan shooting ke gawang dalam permainan sepakbola pada siswa SMAN 2 Kolaka dengan nilai beta yaitu 0,227 dengan tingkat signifikan 0,044 < $\alpha 0,05$; (5) Ada pengaruh langsung percaya diri terhadap kemampuan shooting ke gawang dalam permainan sepakbola pada siswa SMAN 2 Kolaka dengan nilai beta yaitu 0,359 dengan tingkat signifikan $0,035<\alpha 0,05 ;(6)$ Ada pengaruh daya ledak tungkai melalui percaya diri terhadap kemampuan shooting ke gawang dalam permainan sepakbola pada siswa SMAN 2 Kolaka dengan nilai beta yaitu $0,260(0,260>0,233)$; (7) Ada pengaruh koordinasi mata kaki melalui percaya diri terhadap kemampuan shooting ke gawang dalam permainan sepakbola pada siswa SMAN 2 Kolaka dengan nilai beta yaitu $0,280(0,280>0,232)$.
\end{abstract}

Kata kunci: daya ledak tungkai, koordinasi mata kaki, percaya diri dan kemampuan shooting

\begin{abstract}
This research is a type of Ex Post Facto research that uses a path analysis research design. The population is all students of SMAN 2 Kolaka who take extracurricular activities with a sample of 30 students. The sampling technique is the total population or saturated sample. The data analysis technique used is descriptive analysis, test requirements, path analysis through the SPSS 20.00 program at a significant level of $95 \%$ or $\alpha 0.05$. The results showed that; (1) There is a direct effect of leg explosive power on self-confidence in students of SMAN 2 Kolaka with a beta value of 0.500 with a significant level of $0.000<\alpha 0.05$; (2) There is a direct effect of ankle coordination on self-confidence in Kolaka $2 \mathrm{ND}$ students with a beta value of 0.505 with a significant level of $0.000<\alpha 0.05$; (3) There is a direct influence of leg explosive power on the ability to shoot at the goal in football games on SMAN 2 Kolaka students with a beta value of 0.419 with a significant level of $0.001<\alpha 0.05$ (4) There is a direct influence on the coordination of the ankle on the ability to shoot into the goal in football games for students of SMAN 2 Kolaka with a beta value of 0.227 with a significant level of $0.044<\alpha 0.05$; (5) There is a direct influence of self-confidence on the ability to shoot at the goal in football games on SMAN 2 Kolaka students with a beta value of 0.359 with a significant level of $0.035<\alpha 0.05$; (6) There is an influence of leg explosive power through self-confidence in the ability to shoot at the goal in a soccer game for students of SMAN 2 Kolaka with a beta value of 0.260 (0.260)
\end{abstract}


0.233); (7) There is an influence of ankle coordination through self-confidence in the ability to shoot into the goal in a soccer game on students of SMAN 2 Kolaka with a beta value of 0.280 $(0.280>0.232)$.

Keywords: Leg explosive power, ankle coordination, self confidence and ability to shoot at goal

\section{PENDAHULUAN}

Olahraga merupakan suatu yang sangat kompleks dengan melibatkan banyak pihak dan pengelolaannya. Peranan olahraga semakin lama semakin penting. Sebab olahraga tidak hanya ikut berperan meningkatkan kesegaran jasmani suatu bangsa, akan tetapi olahraga juga ikut andil dalam membentuk watak manusia, yang pada gilirannya olahraga akan membawa keharuman nama suatu bangsa.

Peningkatan prestasi olahraga dengan penerapan ilmu pengetahuan dan teknologi dalam suatu bentuk usaha yang diperoleh berdasarkan metode ilmiah yakni melalui prosedur penelitian. Hasil-hasil penelitian dalam bidang olahraga dapat dimanfaatkan untuk meningkatkan prestasi olahraga melalui penelitian dapat dikemukakan halhal baru atau menguji kebenaran suatu pendapat, sehingga dapat dimanfaatkan dalam usaha pembinaan ke arah prestasi, termasuk peningkatan prestasi cabang olahraga sepakbola.

Dalam usaha meningkatkan prestasi olahraga, khususnya cabang olahraga sepakbola, maka setiap individu telah memilih keolahragaan sebagai bidang profesinya. Harus berusaha sekuat mungkin memecahkan masalah-masalah yang merupakan hambatan terwujudnya perkembangan dan peningkatan prestasi olahraga. Di Sulawesi Selatan, sepakbola merupakan cabang olahraga yang sudah mulai diminati para pelajar, mahasiswa, maupun kalangan masyarakat. Ini terlihat dari hampir setiap sekolah, hanya dalam hal kompetisi antar pelajar, mahasiswa dan klub masih belum berjalan lancar, akibatnya berdampak pada perkembangan prestasi yang sangat lambat. Hal inilah yang menjadi masalah terutama bagi para pembina dan pelatih sepakbola di Sulawesi Selatan. Dengan demikian solusi yang terbaik adalah perlunya dilakukan penelitian ilmiah terhadap berbagai hal yang menunjang peningkatan prestasi, seperti keberadaan komponen fisik, teknik, psikologi dan anthropometrik yang dapat dilibatkan dalam meningkatkan kemampuan dan keterampilan teknik pada cabang olahraga termasuk cabang olahraga sepakbola.

Permainan sepakbola sebagai suatu cabang olahraga memiliki teknik-teknik dasar tertentu, seperti; menggiring, passing, heading, lemparan ke dalam dan, shooting, dan lain-lain. Teknik-teknik dasar tersebut harus dapat dikuasai oleh seorang pemain untuk dapat memainkan permainan dengan tingkat keterampilan yang tinggi sesuai dengan kesatuan permainan sepakbola. Dari berbagai teknik permainan sepakbola, dalam proposal ini hanya akan dibahas teknik dasar shooting ke gawang.

Shooting bola adalah salah satu teknik yang terdapat pada permainan sepakbola. Shooting bukan merupakan gerakan yang harus dikuasi bagi siswa. Hal ini disebabkan karena pada waktu melakukan gerakan tersebut siswa harus mempunyai penguasan teknik shooting dengan baik dalam arti siswa dapat melakukan shooting dengan baik dan benar. Daya ledak tungkai merupakan komponen fisik yang banyak dibutuhkan pada setiap cabang olahraga khususnya olahraga sepakbola. Dalam melakukan shooting ke gawang, dibutuhkan daya ledak pada tungkai agar hasil tendangan yang dilakukan bisa sempurna. Karena dengan memiliki daya ledak tungkai maka shooting yang dilakukan akan keras hasil tendangan yang dilakukan dan juga penjaga gawang akan kesulitan dalam menangkap bola. Jadi, daya ledak atau power merupakan kemampuan seseorang dalam memadukan antara kekuatan dan kecepatan maksimal dalam melakukan aktivitas. Dengan demikian dalam 
melakukan shooting ke gawang dibutuhkan daya ledak tungkai atau power tungkai.

Salah satu komponen yang sangat penting juga adalah koordinasi mata kaki. Koordinasi mata kaki merupakan kemampuan dalam memadukan antara mata dengan kaki dan mata dengan bola dalam melakukan tendangan. Dalam shooting ke gawang dalam permainan sepakbola dibutuhkan perkenaan bola dengan kaki agar hasil tendangan yang dilakukan bisa sesuai dengan sasaran yang diinginkan. Maka dari itu dalam melakukan shooting dibutuhkan koordinasi mata kaki yang sempurna. Apabila seorang pemain atau siswa tidak memiliki koordinasi mata kaki yang baik maka shooting yang dilakukan akan kesulitan dalam melakukan sasaran yang diinginkan bahkan dapat menjahui sasaran.

Selain kedua komponen fisik di atas, salah satu yang paling penting yang diberikan seorang pemain adalah psikologis siswa seperti percaya diri pada saat bermain sepakbola ataupu melakukan teknik dasar permainan sepakbola. Percaya diri adalah sikap positif seorang individu yang memampukan dirinya untuk mengembangkan penilaian positif terhadap diri sendiri maupun terhadap lingkungan/situasi yang dihadapinya. Dalam melakukan shooting ke gawang biasanya para pemain atau siswa tidak percaya diri dalam melakukan shooting karena dipikirannya masih takut apabila hasil shooting yang dilakukan tidak akan masuk ke gawang bahkan melenceng jauh dari gawang. Maka dari itu, peran pelatih ataupun pembina dalam membina anak didiknya harus dipenuhi psikologis percaya diri pada pemain atau siswa agar memiliki keberanian untuk melakukan shooting ke gawang.

Pada siswa SMAN 2 Kolaka merupakan salah satu sekolah yang ada di Kab. Kolaka yang selau ikut serta dalam setiap pertandingan yang ada di Kab. Kolaka akan tetapi sekolah tersebut tidak pernah lolos dibabak kualifikasi. Dari hasil tinjauan tersebut, kebanyakan siswa yang main sudah selesai atau tamat pada sekolah tersebut. Dari hasil observasi pad siswa SMAN 2 Kolaka sekarang, kebanyakan siswa masih belum menguasai beberapa teknik khususnya teknik dasar shooting ke gawang dan juga sekolah tersebut belum perna ada yang melakukan penelitian sebelumnya. Kesalahan pada saat melakukan shooting, siswa kebanyakan shooting yang dilakukan tidak terarah, hasil shooting yang dilakukan tidak terlalu keras. Teknik dasar shooting ke gawang

Shooting sangat penting ketika pemain dan bola berada didaerah penalti lawan kecuali jika seorang pemain dihalangi atau dijaga ketat oleh pemain bertahan lawan, tindakan yang tepat dalam daerah penalty adalah melakukan shooting". Salanjutnya Robert Koger (2007) dalam Mahmuddin dan Tarmizi (2017:18) menyatakan: "keahlian menyarangkan bola ke gawang sangat penting untuk menyetak angka. Jika pemain tidak dapat menembak bola dengan tepat ke gawang, mereka tidak dapat memenangkan pertandingan". Cliffe Gifford (2007:22) dalam Mahmuddin dan Tarmizi (2017:18) mengatakan bahwa: "ketika kamu melakukan tembakan, tidak ada gunanya menendang bola dengan sangat keras jika tidak tepat sasaran. Di dekat gawang kamu dapat melakukan tembakan dengan sisi kaki, untuk jarak yang lebih jauh cobalah menggunakan cara tembak dengan kurakura kaki”.

\begin{tabular}{lllr}
\multicolumn{2}{c}{ Berhubungan } & dengan & kualitas \\
tendangan atau shooting & dengan \\
serangkaian & gerakannya Brown & (1980)
\end{tabular} dalam Effendi (2016:94) mengemukakan: Hitting on or above the centre line of the ball will keep the ball down where as just the opposite will occur if contact is made below the midle line, striking the ball on the left side of the ball cause it to swing to the right and viee - versa, yang artinya, bila bola ditendang pada bagian bawahnya, maka bola itu akan melambung, bila ditendang tengahnya bola akan berjalan datar dan apabila bola ditendang pada bagian kiri maka akan bergulir ke arah kanan begitu juga sebaliknya. 
Terdapat langkah-langkah dari menendang bola menurut Haddade dan Tola (1991:59) sebagai berikut:

a. Sikap awalan menendang bola

Badan di belakang bola sedikit condong ke depan, kaki tumpu diletakkan di samping bola dengan ujung kaki menghadpa ke sasaran, dan lutut sedikit ditekuk. Kaki tendang berada di belakang bola dengan bagian kaki (kaki dalam, punggung kaki dan kaki bagian luar) menghadap ke depan/sasaran. Kaki tending tarik ke belakang dan ayunkan ke depan sehingga mengenai bola.

b. Perkenaan kaki dengan bola

Perkenaan kaki pada bola tepat pada dalam kaki, punggung kaki dan bagian luar kaki penuh dan tepat pada tengahtengah bola dan pada saat mengenai bola pergelangan kaki ditegangkan.

c. Gerakan lanjutan

Gerak Ianjut kaki tendang diarahkan dan diangkat ke arah sasaran. Pandangan mengikuti jalannya bola dan ke sasaran.

Abdoellah (1981) dalam Istofian dan Amiq (2016:108) menyatakan bahwa: "shooting adalah tendangan bola untuk mencetak gol atau membuat gol". Shooting merupakan salah satu cara untuk memasukkan bola atau menciptakan gol ke gawang lawan dengan menggunakan kaki sebagai subyek geraknya. Jadi, shooting adalah faktor yang paling penting dalam melakukan penyelesaian akhir. Teknik yang buruk dalam shooting sering menyebabkan peluang mencetak gol menjadi terlewatkan. Menendang bola merupakan salah satu karakteristik permainan permainan sepakbola yang paling dominan. Tujuan utama menendang bola menurut Ariston (2016:5) adalah untuk mengumpan (passing), dan menembak kearah gawang (shootig at the goal). Dilihat dari perkenaan bagian kaki ke bola, menendang dibedakan menjadi berbagai macam, yaitu menendang dengan kaki bagian dalam, menendang dengan kaki bagian luar, dan menendang dengan punggung kaki
Secara teknis, teknik shooting adalah salah satu metode yang digunakan para pemain sepakbola untuk menciptakan gol, dan secara teoritis teknik tersebut dapat dilakukan dengan bermacam cara dan fariasi teknik shooting. Banyak sekali fariasi yang dapat dilakukan oleh para pemain sepakbola, mulai knuckleball atau shooting menggunakan kaki bagian kura-kura, rate comment (shooting menggunakan kaki bagian dalam) dan masih banyak yang lainnya. Faktor yang mempengaruhi hasil teknik shooting (menembak) menurut Putra dan Junaidi (2013:35) adalah: "perkenaan bola, kekuatan otot tungkai, posisi badan saat melakukan shooting dan menggunakan teknik shooting secara benar". Sedangkan menurut Ariston (2016:2) mengatakan Kemampuan shooting bola ke gawang dalam permainan sepakbola adalah: "Teknik dasar yang sangat menunjang keberhasilan prestasi optimal bagi pemain sepakbola". Teknik dasar bermain sepakbola tersebut perlu dipelajari dengan tekun dan terus menerus agar dapat dicapai otomatisasi gerakan yaitu gerakan shooting bola yang terarah dan akurat yang dapat menghasilkan terciptanya gol.

Daya Ledak Tungkai

Menurut Harsono (1988:176) mengatakan bahwa: "Power adalah hasil dari kekuatan dan kecepatan". Sedangkan Ramli (2015:104) mengatakan bahwa: "power adalah kemampuan otot untuk mengarahkan kekuatan maksimal dalam waktu yang sangat cepat". Kekuatan adalah kemampuan komponen fisik seseorang dalam mempergunakan otot untuk menerima beban sewaktu bekerja, sedangkan kecepatan adalah kemampuan untuk melakukan gerakan yang sejenisnya secara berturut-turut dalam waktu yang singkat.

Power atau daya ledak sering juga disebut eksplosif power atau muscular power. Menurut Harsono (1988:200) bahwa "Power adalah kemampuan otot untuk mengarahkan kekuatan maksimal, dalam waktu yang sangat cepat". Kemudian menurut Sajoto (1995:8) bahwa: "Daya 
ledak otot (Muscular power) adalah kemampuan seseorang untuk melakukan kekuatan maksimum, dengan usaha yang dikerahkan dalam waktu yang sependekpendeknya". Nala (2011:16) mengemukakan bahwa: "Daya ledak adalah kemampuan untuk melakukan aktivitas secara tiba-tiba dan cepat dengan menggerahkan seluruh kekuatan dalam waktu yang singkat". Menurut Widiastuti (2011:100) bahwa: "power atau sering pula disebut daya eksplosif adalah suatu kemampuan gerak yang sangat penting untuk menunjang aktivitas pada setiap cabang olahraga".

Pada dasarnya power merupakan kemampuan seseorang untuk mengerahkan kekuatan secara maksimal dalam waktu sependek-pendeknya, sehingga unsur utamanya adalah kekuatan dan kecepatan. Menurut Harsono (1988:200) bahwa: "seorang individu yang mempunyai power adalah orang yang mempunyai: (1) a high decree muscular strength, (2) a hingh degree of speed, (2) a high decree a skill in integrating speed and muscular strength".

Faktor utama daya ledak otot adalah kekuatan dan kecepatan, semua faktor yang mempengaruhi kedua hal tersebut diatas akan mempengaruhi tenaga ledak otot. Power otot juga dipengaruhi oleh ketrampilan teknik dan koordinasi gerakan yang baik. Power tungkai dapat ditingkatkan dengan memberikan latihan kecepatan dan kekuatan otot serta meningkatkan efisiensi dan koordinasi gerakan.

Berdasarkan hal tersebut, kekuatan Power khususnya otot tungkai mempunyai peranan penting untuk mencapai kemampuan lompat jauh. Power tungkai berperan penting dalam melakukan lompatan yang tinggi pada saat menumpu dan tolakan kaki dengan sudut tertentu. Menurut Noer (2002:140) mengatakan bahwa: "Eksplosif power adalah merupakan kemampuan otot atau segerombolan otot untuk melawan beban/tahanan dengan kecepatan tinggi dalam satu gerakan". Menurut Bompa (1994:233) mengatakan bahwa: "power adalah hasil dari kedua kemampuan; kecepatan maksimal dan kekuatan maksimal dalam waktu yang sesingkat mungkin". Power otot tungkai merupakan komponen yang sangat penting dalam pencapaian prestasi yang maksimal pada sudut tolakan terhadap nilai power. Hal ini disebabkan karena dengan memiliki power yang besar pada otot tungkai maka seorang atlet akan dapat mengatasi beban atau tahanan guna melakukan shooting ke gawang untuk mencapai nilai power yang maksimal.

Menurut Sajoto (1988:53) bahwa: "koordinasi adalah kemampuan untuk menyatukan berbagai system syaraf gerak, yang terpisah, ke dalam satu pola gerak yang efisien". Jadi, koordinasi dapat dikatakan bahwa kemampuan untuk melakukan gerakan dengan berbagai tingkat kesukaran dengan cepat dan efisien dan penuh ketepatan. Menurut Kerkindall, J.

Metode pelatihan komponen koordinasi ini tidaklah sama seperti melatih komponen biomotorik lainnya. Lagi pula komponen ini lebih bersifat genetik. Bagi mereka yang tidak di anugrahi bakat alami ini akan lebih sulit untuk melatih koordinasinya. Latihan yang baik untuk memperbaiki koordinasi adalah dengan melakukan berbagai vareasi gerak dan keterampilan atlet-atlet yang mempunyai spesialisasi suatu cabang olahraga tertentu sebaiknya dilibatkan didalam keterampilan dalam berbagai cabang olahraga lainnya. Menurut Harre dalam Harsono (1988:223) menganjurkan latihan-latihan antara lain:

a. Latihan-latihan dengan perubahan kecepatan dan irama.

b. Latihan-latihan dalam kondisi lapangan dan peralatan yang berubah-ubah, memperkecil dan memperluas lapangan.

c. Kombinasi berbagai latihan senam.

d. Kombinasi berbagai permainan.

e. Latihan-latihan untuk mengembangkan reaksi.

f. Latihan didepan kaca, latihan keseimbangan, latihan dengan mata tertutup. 
g. Melakukan gerakan-gerakan yang kompleks pada akhir latihan.

h. Latihan keseimbangan segera setelah melakukan koprol bebeerapa kali atau setelah berputa-putar ditempat.

Menurut Halim

(2011:131)

mengatakan bahwa: "komponen yang erat kaitannya dengan koordinasi adalah kecepatan, kekuatan, daya tahan, kelentukan kelincahan dan keseimbangan". Sedangkan menurut Sugianto; Sudjawo (2002:118) mengatakan bahwa: "Koordinasi adalah kemampuan untuk mengontrol gerakan tubuh". Seseorang dikatakan koordinasinya baik apabila ia mampu bergerak dengan mudah, lancer dalam rangkaian gerakannya serta iramanya terkontrol dengan baik.

Percaya Diri

Salah satu modal utama dan syarat mutlak untuk mencapai prestasi olahraga gemilang adalah yang memiliki percaya diri (self confidence atau confidence in oneself). Secara sederhana percaya diri berarti rasa percaya terhadap kemampuan atau kesanggupan diri untuk mencapai prestasi tertentu. Komaruddin (2015:65) mendefenisikan bahwa: penampilan terbaik adalah korelasi langsung antara kepercayaan diri yang tinggi dan keberhasilan performa olahraga". Jelaslah bahwa percaya pada diri sendiri merupakan modal utama untuk berprestasi. Mulyana (2006:13) mendefenisikan bahwa:

Rasa percaya diri yang tinggi sebenarnya hanya merujuk pada pada adanya beberapa aspek dari kehidupan individu tersebut dimana ia merasa memiliki kompetensi, yakin, mampu dan percaya bahwa dia bisa karena didukung oleh pengalaman, potensi actual, prestasi serta harapan yang realistik terhadap diri sendiri.Sedangkan menurut Setyobroto (2001:71) mengemukakan bahwa: "Percaya diri adalah biasanya berhubungan erat dengan "emotional security" makin matap kepercayaan diri sendiri makin mantap pula emotionalnya securitynya; hal ini akan terlihat pada sikap dan tingkah laku yang tidak mudah bimbang, tegang, tegas dan sebagainya". Percaya diri atau self confidence merupakan modal utama seorang atlet untuk dapat maju, karena pencapaian prestasi yang tinggi dan pemecahan rekor atlet itu sendiri harus dimulai dengan percaya bahwa ia dapat dan sanggup melampaui prestasi yang pernah dicapainya. Tanpa memiliki penuh rasa percaya diri sendiri atlet tidak akan dapat mencapai prestasi tinggi. Atlet pada umumnya lebih sering menghadapi situasi-situasi penuh ketegangan dibanding bukan atlet. Situasi penuh ketegangan timbul karena atlet takut atau bimbang menghadapi sesuatu yang dapat mengancam harga dirinya, sehingga berakibat timbul stress pada atlet yang bersangkutan.

Dalam olahraga, kepercayaan diri sudah pasti menjadi salah satu faktor penentu suksesnya seorang atlet. Masalah kurang atau hilangnya rasa percaya diri terhadap kemampuan diri sendiri akan mengakibatkan atlet tampil di bawah kemampuannya. Karena itu sesungguhnya atlet tidak perlu merasa ragu akan kemampuannya, sepanjang ia telah berlatih secara sungguh-sungguh dan memiliki pengalaman bertanding yang memadai. Menurut Weinberg (1995:89) mengemukakan bahwa: "esensi percaya diri adalah kepercayaan bahwa diri anda bisa menampilkan keberhasilan sesuai dengan perilaku yang digunakan". Sedangkan menurut Husdarta (2010:92) mengatakan bahwa: "Secara sederhana percaya diri berarti rasa percaya diri terhadap kemampuan atau kesanggupan diri untuk mencapai prestasi tertentu". Misalnya memukul, menendang, menghindari cedera dan sebagainya. Semua itu bisa dicapai jika atlet memiliki kepercayaan diri sendiri. Atlet yang memiliki percaya diri berarti atlet dapat melakukan tugas-tugasnya dengan baik, atlet percaya pada kemampuan dirinya untuk memeperoleh berbagai kompetisi dan keterampilan yang dibutuhkanya baik fisik maupun mental untuk mencapai kemampuannya. 
Mylsida (2015:110), Ada beberapa cara untuk membangkitkan self confidence pada diri atlet apabila mengalami penurunan self confidence dalam pertandingan sebagai berikut:

a. Membangkitkan kembali ingatan pada kesuksesan yang pernah diraih dimasa lalu

b. Mengingat kembali kekuatan yang ada pada diri, kuatkan kenyataan bahwa bermain dimasa lalu berarti dapat mengulanginya

c. Mempercayai pada kemampuan dan diri sendiri

d. Menghindari menghakimi diri sendiri

e. Jangan terlalu berhati-hati agar tidak melakukan kesalahan selama bertanding.

Seorang atlet untuk dapat berprestasi harus ada kepercayaan pada diri sendiri bahwa ia sanggup dan mampu mencapai prestasi yang di inginkan. Menurut Husdarta (2010:93) bahwa untuk sampai pada tangga juara yang paling tinggi seorang atlet harus full confidence, karena sikap mentalnseperti ini akan sangat membantu dalam proses adaptasi menghadapi ketegangan yang berlebihan, mamantapkan emotional security-nya, berusaha mencapai target yang ditetapkannya sendiri, dan menghindarkan atlet dari perasaan frustasi karena kegagalan.

Sukses-sukses yang pernah dialami oleh seorang atlet akan dapat menimbulkan rasa percaya diri, oleh karena itu perlu sekali atlet-atlet pemula mendapat kesempatan mengeyam kemenangan. Suatu kekalahan juga tidak harus mengakibatkan kerugian pada usaha menanamkan rasa percaya diri sendiri. Hal ini tergantung peran pelatih dan pembina dalam mengadakan pendekatan dan teknik menimbulkan motivasi; dengan menunjukkan kelemahan dan kelebihan lawan, disamping itu juga menunjukkan rasa puas atas hasil yang dicapai atlet.

\section{METODE}

Jenis penelitian yang dilaksanakan adalah Ex Post Facto. Lokasi penelitian yang dipilih adalah SMAN 2 Kolaka, Jl.
Badewi no.73 Kec. Kolaka Kab. Kolaka. Menurut Sudaryono, Margono dan Rahayu, (2013:20) mengatakkan bahwa: "variabel penelitian pada dasarnya adalah segala sesuatu yang berbentuk apa saja yang ditetapkan oleh peneliti untuk dipelajari sehingga diperoleh informasi tentang hal tersebut, kemudian ditarik kesimpulannya". Adapun variabel yang ingin diteliti adalah: a) Variabel bebas (Independent Variable) yaitu Daya ledak tungkai dan Koordinasi Mata Kaki; b) Variabel Moderating (Modetare Variable) yaitu Percaya Diri; dan c) Variabel Terikat (Dependent Variable) yaitu Kemampuan shooting ke gawang dalam permainan sepakbola.

Desain penelitian atau rancangan penelitian yang digunakan dalam penelitian ini adalah desain penelitian Analisis Jalur (Path Analisys). Untuk menghindari penafsiran yang meluas tentang variabelvariabel yang terlihat dalam penelitian ini, maka variabel-variabel tersebut perlu didefinisikan sebagai berikut:

1. Daya ledak tungkai yang dimaksud dalam penelitian ini adalah kemampuan dalam memadukan antara kekuatan dan kecepatan maksimal. Tes yang digunakan adalah lompat tanpa awalan.

2. Koordinasi mata kaki yang dimaksud dalam penelitian ini adalah kemampuan seseorang dalam memadukan antara mata dengan bola dan kaki agar perkenaan bola dengan kaki bisa sempurna. Untuk mengukur kemampuan seorang digunakan tes sepak tahan bola.

3. Percaya diri yang dimaksud dalam penelitian ini adalah sikap positif seorang individu yang memampukan dirinya untuk mengembangkan penilaian positif terhadap diri sendiri maupun terhadap lingkungan/situasi yang dihadapinya. Dalam hal penelitian ini diukur dengan menggunakan angket.

4. Kemampuan shooting ke gawang dalam permainan sepakbola yang dimaksud dalam penelitian ini adalah 
kemampuan seseorang dalam melakukan tendangan ke gawang dengan sasaran yang sudah ditentukan. Tes yang digunakan yaitu tes melakukan shooting dengan sasaran yang sudah ditentukan di gawang.

Menurut Abdullah (2015:226) mengatakan bahwa: "Populasi adalah kumpulan unit yang akan diteliti ciri-ciri (karakteristik), dan apabila populasinya terlalu luas, maka peneliti harus mengambil sampel (bagian dari populasi) itu untuk diteliti”. Bertolak dari pengertian di atas, maka ditarik suatu makna bahwa seluruh obyek yang memiliki karakteristik tertentu diistilahkan sebagai populasi. Jadi, yang menjadi populasi dalam penelitian ini adalah siswa SMAN 2 Kolaka kelas X dan XI dengan jumlah populasi 150 siswa. Dengan demikian sampel yang digunakan dalam penelitian ini adalah siswa SMAN 2 Kolaka sebanyak 30 siswa dengan tehnik pengambilan sampel adalah total populasi atau sampel jenuh.

\section{HASIL DAN PEMBAHASAN}

Tabe 1. Pengujian Hipotesis Sub Strukur I

\begin{tabular}{c|c|c|c}
\hline VARIABEL & BETA & Sig & $\boldsymbol{\alpha}$ \\
\cline { 1 - 1 } $\begin{array}{c}\text { Daya ledak } \\
\text { tungkai }\end{array}$ & 0,482 & 0,000 & 0,05 \\
\cline { 1 - 2 } Percaya diri & 0,519 & 0,000 & 0,05 \\
\cline { 1 - 2 } $\begin{array}{c}\text { Koordinasi mata } \\
\text { kaki }\end{array}$ & 0,000 & \\
\cline { 1 - 2 } Percaya diri &
\end{tabular}

a. Koefisien persamaan struktural untuk variabel daya ledak tungkai terhadap percaya diri pada siswa SMAN 2 Kolaka sebesar 0,582. Sedangkan nilai signifikan yang diperoleh untuk variabel daya ledak tungkai adalah 0,000. Karena nilai signifikan kurang dari $0,05(0,000<0,05)$ maka dapat diambil keputusan $\mathrm{H}_{0}$ ditolak. Artinya terdapat pengaruh langsung yang signifikan daya ledak tungkai terhadap percaya diri pada siswa SMAN 2 Kolaka

b. Koefisien persamaan struktural yang diperoleh untuk variabel koordinasi mata kaki terhadap percaya diri pada siswa SMAN 2 Kolaka adalah 0,519. Sedangkan nilai signifikan yang diperoleh adalah 0,000. Karena nilai signifikansi kurang dari $0,05(0,000<$ 0,05) maka dapat diambil kesimpulan $\mathrm{H}_{0}$ ditolak. Artinya terdapat pengaruh langsung yang signifikan koordinasi mata kaki terhadap percaya diri pada siswa SMAN 2 Kolaka.

Tabe 2. Pengujian Hipotesis Sub Struktur II

\begin{tabular}{|c|c|c|c|}
\hline \multicolumn{4}{|c|}{ sub struktur 11} \\
\hline VARIABEL & BETA & Sig & $\alpha$ \\
\hline $\begin{array}{c}\text { Daya ledak } \\
\text { tungkai }\end{array}$ & \multirow[b]{2}{*}{0,233} & \multirow[b]{2}{*}{0,011} & \multirow[b]{2}{*}{0,05} \\
\hline $\begin{array}{c}\text { Kemampuan } \\
\text { shooting ke } \\
\text { gawang }\end{array}$ & & & \\
\hline $\begin{array}{c}\text { Koordinasi } \\
\text { mata kaki }\end{array}$ & \multirow[b]{2}{*}{0,232} & \multirow[b]{2}{*}{0,015} & \multirow[b]{2}{*}{0,05} \\
\hline $\begin{array}{c}\text { Kemampuan } \\
\text { shooting ke } \\
\text { gawang } \\
\end{array}$ & & & \\
\hline Percaya diri & \multirow[b]{2}{*}{0,540} & \multirow[b]{2}{*}{0,000} & \multirow[b]{2}{*}{0,05} \\
\hline $\begin{array}{c}\text { Kemampuan } \\
\text { shooting ke } \\
\text { gawang } \\
\end{array}$ & & & \\
\hline
\end{tabular}

a. Nilai koefisien persamaan struktural untuk variabel daya ledak tungkai terhadap kemampuan shooting ke gawang dalam permainan sepakbola pada siswa SMAN 2 Kolaka sebesar 0,233 dengan signifikan yang diperoleh adalah 0,011. Karena nilai signifikan kurang dari $0,05(0,011<0,05)$ maka dapat diambil keputusan $\mathrm{H}_{0}$ ditolak. Artinya terdapat pengaruh langsung yang signifikan daya ledak tungkai terhadap kemampuan shooting ke gawang dalam permainan sepakbola pada siswa SMAN 2 Kolaka

b. Nilai koefisien koordinasi mata kaki terhadap kemampuan shooting ke 
gawang dalam permainan sepakbola pada siswa SMAN 2 Kolaka sebesar 0,232 dengan signifikan yang diperoleh 0,015 . Karena nilai signifikan kurang dari $0,05(0,015<0,05)$ maka dapat diambil keputusan $\mathrm{H}_{0}$ ditolak. Artinya terdapat pengaruh langsung yang signifikan koordinasi mata kaki terhadap kemampuan shooting ke gawang dalam permainan sepakbola pada siswa SMAN 2 Kolaka

c. Nilai koefisien percaya diri terhadap kemampuan shooting ke gawang pada siswa SMAN 2 Kolaka sebesar 0,540 dengan signifikan yang diperoleh 0,000. Karena nilai signifikan kurang dari $0,05(0,000<0,05)$ maka dapat diambil keputusan $\mathrm{H}_{0}$ ditolak. Artinya terdapat pengaruh langsung yang signifikan percaya diri terhadap kemampuan shooting ke gawang dalam permainan sepakbola pada siswa SMAN 2 Kolaka.

Pada hipotesis keenam diketahui nilai koefisien beta pengaruh langsung daya ledak tungkai terhadap percaya diri pada siswa SMAN 2 Kolaka adalah 0,482 dan nilai koefisien beta pengaruh langsung percaya diri terhadap kemampuan shooting ke gawang dalam permainan sepakbola pada siswa SMAN 2 Kolaka adalah 0,540. Maka nilai koefisien beta pengaruh daya ledak tungkai melalui percaya diri terhadap kemampuan shooting ke gawang dalam permainan sepakbola pada siswa SMAN 2 Kolaka adalah $(0,482 * 0,540=0,260)$. Hasil ini menunjukkan nilai koefisien beta tersebut lebih besar dibanding nilai koefisien beta pengaruh langsung daya ledak tungkai terhadap kemampuan shooting ke gawang dalam permainan sepakbola sebesar $0,233(0,233<0,260)$. Sehingga dapat disimpulkan bahwa terdapat pengaruh daya ledak tungkai melalui percaya diri terhadap kemampuan shooting ke gawang dalam permainan sepakbola pada siswa SMAN 2 Kolaka.

Pada hipotesis ketujuh diketahui nilai koefisien beta pengaruh langsung koordinasi mata kaki terhadap percaya diri pada siswa SMAN 2 Kolaka adalah 0,519 dan nilai koefisien beta pengaruh langsung percaya diri terhadap kemampuan shooting ke gawang dalam permainan sepakbola pada siswa SMAN 2 Kolaka adalah 0,540. Maka nilai koefisien beta pengaruh tidak langsung koordinasi mata kaki melalui percaya diri terhadap kemampuan shooting ke gawang pada siswa SMAN 2 Kolaka adalah $(0,519 * 0,540=0,280)$. Hasil ini menunjukkan nilai koefisien beta tersebut lebih besar dibanding nilai koefisien beta pengaruh langsung koordinasi mata kaki terhadap kemampuan shooting ke gawang dalam permainan sepakbola pada siswa SMAN 2 Kolaka sebesar 0,232 (0,232 < 0,280). Sehingga dapat disimpulkan bahwa terdapat daya ledak tungkai melalui percaya diri terhadap kemampuan shooting ke gawang dalam permainan sepakbola pada siswa SMAN 2 Kolaka.

\section{PENUTUP}

Berdasarkan hasil-hasil dan temuan sebagaimana yang telah dikemukakan pada bagian Bab IV penelitian ini, maka dapat dibuat kesimpulan sebagai berikut.

\section{Simpulan}

1. Ada pengaruh langsung daya ledak tungkai terhadap percaya diri pada siswa SMAN 2 Kolaka.

2. Ada pengaruh langsung koordinasi mata kaki terhadap percaya diri pada siswa SMAN 2 Kolaka.

3. Ada pengaruh langsung daya ledak tungkai terhadap kemampuan shooting ke gawang dalam permainan sepakbola pada siswa SMAN 2 Kolaka

4. Ada pengaruh langsung koordinasi mata kaki terhadap kemampuan shooting ke gawang dalam permainan sepakbola pada siswa SMAN 2 Kolaka

5. Ada pengaruh langsung percaya diri terhadap kemampuan shooting ke gawang dalam permainan sepakbola pada siswa SMAN 2 Kolaka

6. Ada pengaruh daya ledak tungkai melalui percaya diri terhadap 
kemampuan shooting ke gawang dalam permainan sepakbola pada siswa SMAN 2 Kolaka

7. Ada pengaruh koordinasi mata kaki melalui percaya diri terhadap kemampuan shooting ke gawang dalam permainan sepakbola pada siswa SMAN 2 Kolaka

\section{Saran}

Dalam hal penelitian ini yang dilakukan peneliti, masih terdapat beberapa batasan yang disadari oleh peneliti. Beberapa hal yang perlu dipahami, baik merupakan konsep metodologi maupun terknis dalam melakukan penelitian ini masih menjadi keterbatasan dalam penelitian. Pada penelitian ini telah dilakukan bebagai upaya untuk menghindari hal-hak yang dapat mengurangi bobot dan hasil penelitian, sehingga hasilnya dapat sesuai dengan tujuan yang ingin dicapai. Namun demikian, diakui masih terdapat beberapa kelemahan dalam penelitian ini, olehnya itu dibutuhkan saran, kritikan dari para pelatih, para guru penjas, para pegiat olahraga dan para pembaca untuk kemajuan penelitian ini.

\section{DAFTAR PUSTAKA}

Abdullah Ma'ruf. 2015. Metodologi Penelitian Kuantitatif. Yogyakarta: Aswaja Pressindo

Arikunto Suharsimi. 2006. Prosedur Penelitian Suatu Pendekatan Praktek. Jakarta: PT. Rineka Cipta.

Atmojo Mulyono Biyakto. 2008. Tes dan Pengukuran dalam Pendidikan Jasmani/Olahraga. Surakarta: LPP UNS dan UNS Press

Darmadi, Hamid. 2013. Metode Penelitian Pendidikan dan Sosial. Bandung: Alfabeta.

Halim, Nur Ichsan. 2011. Tes dan Pengukuran Dalam Bidang Olahraga. Makassar: Universitas Negeri Makassar.

Husdarta. 2010. Psikologi Olahraga. Bandung : Alfa Beta
Komarudin. 2015. Psikologi Olahraga: Latihan Keterampilan Mental dalam olahraga Kompetitif. Bandung : Remaja Rosdakarya

Muhajir. 2006. Pendidikan Jasmani Olahraga \& Kesehatan. Bandung: Yudhistira.

Mulyana, Deddy. 2006. Metode Penelitian Kualitatif. Bandung : PT. Remaja.

Mylsidayu, Apta; Kurniawan, Feby. 2015. Ilmu Kepelatihan Dasar. Bandung: Alfabeta

Nala, I Gusti Ngurah. 2011. Prinsip Pelatihan Fisik Olahraga. Denpasar: Udayana University Press.

Raharjo, K., Syafrial, S., \& Sugiyanto, S. (2017). Upaya Meningkatkan Hasil Akurasi Shooting Olahraga Sepakbola Melalui Media Lingkaran Karet Ban Pada Siswa Kelas Xi Ips 2 SMA Negeri 03 Bengkulu Tengah. Kinestetik, 1(2).

Riduwan. 2014. Metode dan Teknik Menyusun Tesis. Bandung: Alfabeta

Sudaryono, Gaguk Margono, Wardani Rahayu. 2013. Pengembangan Instrumen Penelitian Pendidikan. Jakarta : Graha Ilmu.

Sugianto., Sadjarwo. 2002. Perkembangan dan Belajar Gerak. Jakarta: Depdiknas.

Sugiyono. 2017. Metode Penelitian Kuantitatif, Kualitatif dan $R \& D$. Jakarta: Alfabeta.

Sulistio, D. (2019). Analisis Kemampuan Teknik Dasar Passing, Dribbling, Dan Shooting Pada Pemain Sepak Bola SSB Putra U 10-12 Tahun Di Kabupaten Kaur. Kinestetik, 3(2), 241-248.

Widiastuti. 2011. Tes dan Pengukuran Olahraga. Jakarta : PT. Bumi Timur Jaya. 